Izvorni znanstveni članak Primljen: 14. svibnja 2021.

doc. dr. sc., mr. art. Tamara Jurkić Sviben

Prihvaćen: 15. srpnja 2021.

Učiteljski fakultet Sveučilišta u Zagrebu

Katedra umjetničkog područja

tamara.jurkicsviben@ufzg.hr

https://orcid.org/0000-0003-4234-9385

Nikola Sebastian Jambrošić, mag. mus., doktorand

Učiteljski fakultet Sveučilišta u Zagrebu

nikola.sebastian.jambrosic@gmail.com

https://orcid.org/0000-0002-9198-2614

\title{
(NE)PJEVANJE ZA VRIJEME PANDEMIJE BOLESTI COVID-19 - MIŠLJENJA I EMOCIONALNI DOŽIVLJAJ UČENIKA OD 5. DO 8. RAZREDA OSNOVNIH ŠKOLA U REPUBLICI HRVATSKOJ
}

Sažetak: Pjevanje je važan čimbenik u nastavi Glazbene kulture te, uz obvezne sadržaje, aktivnost koja se najviše provodi. Znanstvena literatura potvrđuje da pjevanje u većoj mjeri kod učenika izaziva pozitivne emocionalne reakcije. Proglašenjem pandemije bolesti COVID-19 u ožujku 2020. godine gotovo sve pjevačke aktivnosti bile su na dulje vrijeme obustavljene.

Cilj istraživanja bio je uočiti postoji li razlika u percepciji nezadovoljstva obustavom pjevanja ovisno o tome jesu li se učenici prije pandemije aktivno i intenzivnije bavili pjevanjem u odnosu na one koji tu aktivnost nisu imali ili su je imali u minimalnoj mjeri.

Prvi problem bio je istražiti postoji li razlika u osobnom nezadovoljstvu (sreći) i percepciji nezadovoljstva obustavom pjevanja ovisno o tome jesu li se učenici aktivno bavili pjevanjem prije pandemije ili nisu te jesu li tijekom pandemije nastavili s pjevanjem u virtualnom okruženju (,online“) ili su sasvim prekinuli s aktivnim pjevanjem. Potvrđene su hipoteze da učenici koji su članovi zbora i/ili ansambala osjećaju intenzivniji nedostatak i osobno nezadovoljstvo obustavom glazbenih aktivnosti tijekom pandemije nego oni koji su se aktivno bavili pjevanjem samo na satu Glazbene kulture te da su učenici koji su se tijekom pandemije bavili muziciranjem u virtualnom okruženju (,,online“) zadovoljniji i pokazuju pozitivnije emocije u odnosu na one koji su se prestali baviti glazbom. Drugi problem bio je istražiti postoji li razlika u percepciji pjevanja uživo i pjevanja u virtualnom okruženju (,,online“). Potvrđeno je da učenici 
koji su iskusili i pjevanje uživo i pjevanje u virtualnom okruženju (,,online“) smatraju da pjevanje uživo ima veći učinak od pjevanja u virtualnom okruženju (,,online“). Rezultati potvrđuju da pjevanje utječe pozitivno na pjevača te da ograničavanje pjevanja intenzivira osobno nezadovoljstvo.

Ključne riječi: COVID-19, nastava na daljinu, osobno zadovoljstvo, pjevanje, skupno muziciranje.

\section{UVOD}

Pjevanje je važna aktivnost $u$ općeobrazovnoj školi na nastavi Glazbene kulture koja se uz obvezne sadržaje najviše provodi. Kroz sve razine osnovnoškolskog obrazovanja na nastavnom satu Glazbene kulture $u$ aktivnost pjevanja običava se uključiti sve učenike što aktivnosti daje široku zastupljenost prema dobi, razini obrazovanja, spolu i vjeri.

Izražavanje pjevanjem je čovjekova imanentna potreba pa nije začudno kada se ističe da je „Kao najelementarniji, najspontaniji i najprirodniji način glazbenog ponašanja čovjeka, pjevanje [je] ona aktivnost koja ne samo da je u nastavi glazbe oduvijek prisutna nego je toj nastavi u najvećem dijelu povijest davala bitan pečat" (Rojko, 2012, str. 54).

S obzirom na to da se ,pjevati [se] može bez poznavanja nota, bez određenog glazbenog obrazovanja i bez suvremene tehnike i tehnologije“ (VidulinOrbanić i Terzić, 2011, str. 142), pjevanje je aktivnost koja se uz obavezno slušanje glazbe prema Kurikulumu za Glazbenu umjetnost i Glazbenu kulturu (Ministarstvo znanosti i obrazovanja, MZO, 2019), najviše provodi gotovo na svim razinama osnovnoškolskog programa.

Aktivnost pjevanja se u glavnini odvija grupno kao dio nastave u razredu ili kao izvannastavna aktivnost pjevanja u ansamblu ili zboru. Pjevanje je i aktivnost koja se kao dio umjetničkog obrazovanja provodi i u obrazovnim programima glazbenih škola, bilo kroz nastavu solfeggia ili obveznog skupnog muziciranja (zbora). Brojna istraživanja bave se i pjevanjem mladih u slobodno vrijeme, tako da je moguće ustvrditi da je pjevanje u raznim oblicima, općenito, jedna od vrlo učestalih i važnih duhovnih potreba za kreativnošću i izražavanjem i njegova važnost prepoznata je i u hrvatskom obrazovnom kurikulu, ali i kurikulima širom svijeta. Tako autorica Radočaj-Jerković (2017b, str. 15) ističe da je ,pjevanje kao izraz osobne, spontane glazbene ekspresije fenomen [je] karakterističan za gotovo sve svjetske kulture [...]. Također, sveprisutna je i važnost utjecaja koji pjesme i pjevanje imaju u djetinjstvu, ali i u (ne)ostvarenju ukupnog glazbenog razvoja djeteta“.

U Kurikulumu za Glazbenu umjetnost i Glazbenu kulturu (MZO, 2019, str. 11) u okviru domene B naglasak je stavljen na susret učenika s glazbom, tj. na glazbene aktivnosti (pjevanje, sviranje, pokret uz glazbu i sl.). Verbalne 
informacije trebaju proizlaziti iz glazbe same. Učenje i poučavanje potrebno je prilagođavati interesima i sposobnostima učenika, a ishodi predmeta se povezuju i nadopunjuju. Upravo je i taj pristup „omogućio kvalitetnije poučavanje aktivnosti razvijanjem pjevačkih vještina, a manje usvajanjem konkretnih pjesama“" (Radočaj-Jerković, 2017b, str. 17). Iz tog razloga učitelj autonomno odabire pjesme te metodičke postupke koji će učenicima pomoći u realizaciji intonativno preciznog i izražajnog pjevanja. U cilju postizanja zadanih ishoda učitelj ima ulogu prisutnog medijatora i neposredno sudjeluje u realizaciji aktivnosti putem ,aktivnog muziciranja“. „U činu pjevanja (bilo koje dobre i primjerene pjesme) na licu mjesta (uz prisutnost učitelja) doživljava se i uči glazba, obogaćuje učenikov emocionalni svijet i izoštruje njegov umjetnički senzibilitet" (Rojko, 2005, str. 13). Kurikulum upućuje na čvrstu povezanost s ostalim poljima umjetničkoga područja te se omogućavaju i poželjne su brojne korelacije s ostalim predmetima, područjima i međupredmetnim temama.

Neki od ciljeva nastave glazbe su: poticati razvoj glazbenih sposobnosti svih učenika u skladu s individualnim sposobnostima pojedinca, omogućiti pozitivan društveno-emocionalni razvoj svih učenika, potaknuti učenike na aktivno bavljenje glazbom i sudjelovanje u kulturnom životu zajednice, potaknuti razvijanje glazbenoga ukusa i kritičkoga mišljenja i osvijestiti vrijednosti kulturne baštine (usp. Kurikulum GKGU, MZO, 2019, str. 8). Stoga se važan dio procesa učenja i poučavanja glazbe odnosi na izbornu i fakultativnu nastavu te izvannastavne i izvanškolske aktivnosti (pjevački zbor, glazbeni sastavi, orkestar, plesne skupine i dr.) u okviru kojih učenici proširuju stečena znanja, vještine i stavove te istodobno sustavno razvijaju svoje interese i ostvaruju kvalitetan osobni i umjetnički rast i razvoj (ibid. 2019, str. 11).

Učenici koji iznimno vole glazbene aktivnosti najčešće pokazuju interes za dodatne glazbene aktivnosti ponuđene u okviru škole (Proleta i Svalina, 2011). Ipak, veći dio učenika, iako ne pohađa dodatne glazbene aktivnosti, voli sudjelovati u njima tijekom nastave Glazbene kulture. Tako je potvrđeno da je pjevanje najzastupljenija aktivnost. U istraživanju Radočaj-Jerković (2017a) $80 \%$ ispitanih učenika istaknulo je da voli pjevati te su zauzeli pozitivan stav prema pjevanju u razredu. Istaknuto je da im je pjevanje najomiljenija aktivnost u nastavi glazbe koju bi većina najradije dodatno usavršila. Učenici koji su izrazili negativniji stav prema pjevanju, njih $20 \%$, kao razlog navode neprimjerene pjesme za njihov uzrast, nesigurnost $u$ javnom individualnom izvođenju te nesigurnost $u$ vlastite pjevačke sposobnosti, stoga prednost daju drugim aktivnostima. Također, rezultati istraživanja ukazuju na to da interes progresivno opada tijekom prelaska učenika u više razrede.

Zborsko pjevanje u školi je jedna od najdostupnijih glazbenih izvannastavnih aktivnosti u koju se uključuju učenici koji pokazuju interes za dodatne glazbene aktivnosti koje se ne održavaju u sklopu predmeta Glazbena kultura (Radočaj-Jerković i sur., 2018). Za njihov interes bitna je motivacija koja je 
potaknuta međusobnim druženjem, mogućnosti zajedničkog muziciranja i nastupanja te zajedničkih putovanja (Vidulin, 2016) što poboljšava njihovu osobnu dobrobit.

Glazbene sposobnosti se, kao i sve ostale sposobnosti, razvijaju tijekom života, stoga je pjevanje vještina koja se može naučiti i uvježbati (Šulentić Begić, 2010). Učiteljevim poticanjem učenika na osnaživanje vlastitih kompetencija u području pjevanja, učenici mogu usvojiti pozitivne potrebe i navike te time znatno pridonijeti pozitivnom učinku za osobno zdravlje i vlastitu dobrobit. Pregledom literature o istraživanju područja pjevanja povezanog uz zdravlje i dobrobit vidljivo je da su navedene teme brojnije u recentnijem razdoblju. Gick (2011) i Clift i sur. (2010) utvrđuju da su istraživanja na tim područjima ograničena opsegom i metodologijom. Isti autori kao poseban problem ističu izazove u definiranju pjevačkog iskustva i definiranju pojma pjevač. Ipak, postojeća kvalitativna istraživanja (Balsnes, 2018; Clift, 2012; Clift i sur., 2010; Cohen, 2009) sugeriraju da bavljenje pjevanjem općenito može biti korisno za tjelesno zdravlje, kao i za psihološku i socijalnu dobrobit te da pjevanje ima istaknutu dobrobit za pjevača sa specifičnim zdravstvenim stanjima (Grape i sur., 2008; Schladt, 2017; Vickhoff i sur., 2013; Williams, 2018). Također, istraživanjima se ukazuje na poboljšanje psihofizičkog stanja pojedinca (Gabrielsson, 2018; Stensaeth, 2018; Theorell, 2014) te razvoj glazbenih vještina i izoštravanje umjetničkog senzibiliteta (Šulentić Begić i Birtić, 2012). Sve navedeno govori u prilog pozitivnim aspektima pjevačkih aktivnosti kod svih dobnih skupina, a posebno mladih.

Proglašenjem pandemije bolesti COVID-19 u ožujku 2020. godine za cijelo čovječanstvo dogodilo se novo, do sada nepoznato, i neobično stanje, kako globalno tako i lokalno. Ograničenja „ostanimo doma/odgovorni“ s prisilnom politikom fizičkog distanciranja, dovela su do brojnih poremećaja u životu pojedinca i zajednice. U skladu s proglašenim potrebama, s mjerama distanciranja, gotovo sve pjevačke aktivnosti na glazbenoj nastavi kao i aktivnosti pjevanja u ansamblu i zboru i u općeobrazovnim školama, ali i u znatnoj mjeri i u glazbenim školama, bile su na duže vrijeme obustavljene ili znatno rjeđe i u vrlo ograničenim uvjetima i okolnostima.

Društvena komunikacija preselila se $u$ virtualnu domenu te je time pandemija promijenila način na koji učitelji i nastavnici podučavaju i način na koji pojedinci virtualno komuniciraju unutar društva. Prisilnim ograničavanjem kretanja i komunikacije uživo (lockdown) doživljen je intenzivan pristup svim mrežnim platformama, uključujući Zoom, Teams, Yammer i brojnim drugim platformama za videokomunikaciju (chat). U nužnosti žurne reakcije na pandemijske okolnosti učitelji su pronašli načine prilagodbe i nova metodička i tehnička rješenja. Neki su aktivnost pjevanja prakticirali koristeći platforme za videokomunikaciju. Ipak, takve platforme nisu bile spremne odgovoriti na potrebe nastave glazbe i pjevanja uživo zbog problema sinkronizacije zvuka što 
posebno otežava istovremeno skupno muziciranje ili ga čini gotovo nemogućim za veću grupu sudionika (Grushka i sur., 2021).

S obzirom na sve navedene društvene okolnosti, društvenu i obrazovnu prilagodbu te rezultate spomenute znanstvene literature da pjevanje u većoj mjeri kod učenika izaziva pozitivne emocionalne reakcije nameće se pitanje: Kakvu je reakciju takva obustava aktivnosti pjevanja izazvala kod učenika kao ključnih dionika obrazovnog procesa?

\section{OSNOVNI CILJ I PROBLEMI ISTRAŽIVANJA}

Potaknuti navedenim pitanjem i pod pretpostavkom da pjevanje i izvođenje glazbe obogaćuje učenikov emocionalni svijet te pruža potencijal za postizanje dobrobiti (Clift i Morrison, 2011; Welch i sur., 2008, 2010 i 2021), provedeno je istraživanje čiji je osnovni cilj bio uočiti postoji li razlika u percepciji nezadovoljstva obustavom pjevanja ovisno o tome jesu li se učenici prije pandemije aktivno i intenzivnije bavili pjevanjem u odnosu na one koji tu aktivnost nisu imali ili su je imali u minimalnoj mjeri.

Iz osnovnog cilja proizašli su sljedeći problemi i hipoteze:

1. Postoji li razlika u osobnom nezadovoljstvu (sreći) i percepciji nezadovoljstva obustavom pjevanja ovisno o tome jesu li se učenici aktivno bavili pjevanjem prije pandemije ili nisu te jesu li tijekom pandemije nastavili s pjevanjem u virtualnom okruženju (online) ili su sasvim prekinuli s aktivnim pjevanjem

H1 čenici koji su članovi zbora i/ili ansambala osjećat će intenzivniji nedostatak i osobno nezadovoljstvo obustavom glazbenih aktivnosti tijekom pandemije bolesti COVID-19 nego oni koji su se aktivno bavili pjevanjem samo na školskom satu

$\mathrm{H} 2$ učenici koji su se tijekom pandemije bavili muziciranjem u virtualnom okruženju (online) bit će zadovoljniji i pokazivati pozitivnije emocije u odnosu na one koji su se prestali baviti glazbom

2. Postoji li razlika u percepciji pjevanja uživo i pjevanja u virtualnom okruženju (online).

H3 učenici koji su iskusili i pjevanje uživo i pjevanje u virtualnom okruženju (online) će smatrati da pjevanje uživo ima veći učinak od pjevanja u virtualnom okruženju (online).

\section{METODOLOGIJA}

Za ispitivanje primijenjena je kvantitativna metoda istraživanja. Pri provjeri postavljenih hipoteza koristilo se testiranje razlike među skupinama (t-test i jednostavna analiza varijance). 
Istraživanje je provedeno na uzorku od 1059 ispitanika $(\mathrm{N}=1059)$, učenica i učenika petih, šestih, sedmih i osmih razreda osnovnih škola iz različitih dijelova Republike Hrvatske.

Upitnik o pjevanju i obustavi pjevanja tijekom pandemije ispitanicima (učenicima) je proslijeđen digitalnim putem posredovanjem njihovih učitelja Glazbene kulture. Učenicima je s obzirom na dob i etički kodeks, zagarantirana anonimnost na način da se nisu prikupljali identifikacijski podatci (ime, prezime, OIB, naziv škole) te na načina da je prethodno tražena suglasnost škole i roditelja.

Upitnik sadrži ukupno dvadeset pitanja raspoređenih u tri djela. U prvom dijelu prikupljali su se opći demografski podatci (spol, godina rođenja, razred, županija) dok su se u drugom dijelu prikupljali podatci o navikama pjevanja učenika prije pandemije, osobnom općem zadovoljstvu i osobnom mišljenju te zadovoljstvu koje se ostvaruje tijekom pjevanja kao i razini zadovoljstva koje učenik osjeća tijekom obustave pjevanja. Trećim dijelom upitnika obuhvaćeni su podatci učenika koji su pjevali uživo pod posebnim uvjetima (nošenje maske, smanjeni broj učenika u razrednom odjelu, tiho pjevanje i sl.) i učenika koji su pjevali u virtualnom okruženju $(\mathrm{N}=273)$, a ispitano je postoji li razlika u percepciji pjevanja uživo i pjevanja u virtualnom okruženju (online).

Od ispitanika se tražilo da u pitanjima od 1 do 14 upišu ili odaberu tražene podatke te u pitanjima od 15 do 20, od kojih svako pitanje sadrži skup tvrdnji, označe u kojoj mjeri se slažu s određenom tvrdnjom, koristeći skalu Likertovog tipa od 5 stupnjeva ( 1 - uopće se ne slažem, 2 - ne slažem se, 3 - niti se slažem, niti se ne slažem, 4 - slažem se, 5 - u potpunosti se slažem).

Također, korišten je Kolmogorov Smirnov test za testiranje normaliteta distribucije te t-test za testiranje značajnosti razlike između dva uzorka.

Uz tablični prikaz i detaljno opisivanje uzorka, u nastavku su prikazane i informacije o pjevanju te deskriptivna obilježja kontinuiranih varijabli.

U Tablici 1. nalaze se podatci o prigodnom uzorku istraživanja $(\mathrm{N}=1059)$.

Tablica 1. Uzorak istraživanja

\begin{tabular}{lr}
\hline & $\mathbf{\%}$ \\
\hline Spol & \\
muško & 45,2 \\
žensko & 54,8 \\
Dob (prema godini rođenja) & \\
11 & 5,9 \\
12 & 27,3 \\
13 & 25,5 \\
14 & 23,1 \\
\hline 15 & 17,8
\end{tabular}


Tablica 1. Uzorak istraživanja (nastavak)

\begin{tabular}{lr}
\hline & $\%$ \\
\hline 16 & 0,4 \\
17 & 0,1
\end{tabular}

Razred

5.

26,0

6.

27,1

7.

24,1

8.

22,9

Županija

Varaždinska

28,1

Osječko-baranjska

16,9

Splitsko-dalmatinska

12,0

Primorsko-goranska

11,2

Grad Zagreb

6,4

Dubrovačko-neretvanska

6,1

Šibensko-kninska

Istarska

4,2

Zagrebačka

3,1

Međimurska

2,5

Sisačko-moslavačka

2,2

Virovitičko-podravska

1,2

Koprivničko-križevačka

1,1

Krapinsko-zagorska

0,1

Rezultati u Tablici 1. pokazuju da se u uzorku nalazilo nešto više učenica $(54,8 \%)$ nego učenika $(45,2 \%)$, ponajviše u dobi od 12 do 14 godina $(75,9 \%)$, po oko četvrtina u svakom od četiri viša razreda osnovne škole. Zastupljenost po županijama je bila raznolika, upravo zbog otežanih okolnosti koje su rezultat restrikcija izazvanih pandemijom.

Tablica 2. Navike pjevanja

\begin{tabular}{lr}
\hline & \% \\
\hline Pjevanje & 55,1 \\
\hline samo na nastavi GK & 22,8 \\
školskom zboru & 7,9 \\
zboru glazbene škole & 7,2
\end{tabular}


$\underline{\text { T. Jurkić Sviben, N. Sebastian Jambrošić: (Ne)pjevanje za vrijeme pandemije ... }}$

Tablica 2. (nastavak) Navike pjevanja

\begin{tabular}{|c|c|}
\hline grupi/bendu u sklopu škole & 2,0 \\
\hline & $\%$ \\
\hline grupi/bendu koji nije u sklopu škole & 3,6 \\
\hline ne pjevam & 13,8 \\
\hline \multicolumn{2}{|c|}{$\begin{array}{l}\text { Godine pjevanja u zboru ili glazbenoj skupini u školskim ili izvanškolskim } \\
\text { aktivnostima }\end{array}$} \\
\hline ne pjevam i nisam nikad pjevao,la & 42,2 \\
\hline prije sam pjevao/la, ali sam s pjevanje prestao/la & 19,6 \\
\hline 1 godina & 6,5 \\
\hline 2 godine & 6,9 \\
\hline 3 godine & 6,4 \\
\hline 4 godine & 5,9 \\
\hline 5 ili više godina & 12,5 \\
\hline \multicolumn{2}{|l|}{ Pjevanje tijekom nastave na daljinu na satu GK } \\
\hline uživo koristeći videopoziv & 12,9 \\
\hline snimili ste pjevanje i slali učitelju & 24,1 \\
\hline niste pjevali & 63,0 \\
\hline \multicolumn{2}{|c|}{ Pjevanje tijekom nastave na daljinu na skupnom muziciranju } \\
\hline uživo koristeći videopoziv & 9,1 \\
\hline snimili ste pjevanje i slali učitelju & 18,3 \\
\hline niste pjevali & 72,6 \\
\hline \multicolumn{2}{|l|}{ Snimili pjesmu kao virtualni razred/zbor } \\
\hline $\mathrm{Da}$ & 11,4 \\
\hline $\mathrm{Ne}$ & 88,6 \\
\hline \multicolumn{2}{|l|}{ učestalost pjevanja prije COVID-19 } \\
\hline ne pjevam & 12,7 \\
\hline samo tijekom nastave GK & 54,2 \\
\hline 2 školska sata & 16,2 \\
\hline 3 školska sata & 7,4 \\
\hline 4 školska sata & 4,8 \\
\hline 5 ili više školskih sati & 4,7 \\
\hline \multicolumn{2}{|l|}{ učestalost pjevanja tijekom COVID-19 } \\
\hline ne pjevam & 24,6 \\
\hline samo tijekom nastave GK & 53,2 \\
\hline 2 školska sata & 12,1 \\
\hline 3 školska sata & 4,5 \\
\hline
\end{tabular}


Tablica 2. (nastavak) Navike pjevanja

\begin{tabular}{lr}
\hline 4 školska sata & 2,2 \\
\hline 5 ili više školskih sati & 3,4 \\
\hline
\end{tabular}

Navike pjevanja prikazane u Tablici 2. pokazuju da više od polovice učenika pjeva samo na satu Glazbene kulture te da ih oko jedne četvrtine pjeva u školskom zboru. U zboru ili glazbenoj skupini pjeva oko trećine učenika i to ponajviše 5 ili više godina (12,9\%). Oni koji su pjevali i koji pjevaju, u 16,2 \% odnosno $12,1 \%$ slučajeva, to čine 2 školska sata. I prije i tijekom pandemije bolesti COVID-19 oko polovine učenika pjevalo je samo na satu Glazbene kulture, prije ih nije pjevalo oko $13 \%$, a tijekom pandemije gotovo dvostruko više $(24,6$ $\%$ ), dok su učenici koji su pjevali tijekom pandemije to činili u manjoj mjeri.

Što se tiče pjevanja tijekom nastave na daljinu, na satu Glazbene kulture, u $63 \%$ slučajeva učenici nisu pjevali, četvrtina je pjevala i slala snimke, a oko $13 \%$ su pjevali tijekom videopoziva. U slučaju nastave na daljinu u skupnom muziciranju (zboru) još je veći udio od gotovo tri četvrtine učenika koji su se izjasnili da nisu pjevali i samo $9,1 \%$ onih koji su pjevali putem videopoziva. I na kraju nešto više od desetine učenika snimilo je pjesmu kao virtualni razred/ zbor tijekom nastave na daljinu.

Nastavak obrade rezultata istraživanja prikazuje deskriptivna obilježja kontinuiranih varijabli vezanih uz osjećaj sreće, zadovoljstva životom, stavom o ukidanju pjevanja te odnosu pjevanja i osobnog zadovoljstva (Tablica 3.).

Tablica 3. Deskriptivna obilježja kontinuiranih varijabli

\begin{tabular}{lcccccccc}
\hline & M & C & SD & Z & min & max & Skew. & Kurt. \\
\hline $\begin{array}{l}\text { 15a Sretna sam osoba. } \\
\text { 15b Kad se usporedim sa }\end{array}$ & 4,1 & 4,0 & 0,94 & $0,25^{* *}$ & 1 & 5 & $-1,23$ & 1,48 \\
$\begin{array}{l}\text { svojim vršnjacima ja sam } \\
\text { manje sretan/a. }\end{array}$ & 2,2 & 2,0 & 1,15 & $0,22^{* *}$ & 1 & 5 & 0,67 & $-0,41$ \\
$\begin{array}{l}\text { 15c Neki su ljudi općenito } \\
\text { vrlo sretni, bez obzira na to }\end{array}$ & 3,3 & 3,0 & 1,19 & $0,18^{* *}$ & 1 & 5 & $-0,34$ & $-0,68$ \\
$\begin{array}{l}\text { što im se događa u životu. } \\
\text { Ja sam takva osoba. }\end{array}$ & & & & & & & & \\
$\begin{array}{l}\text { 15d Neki ljudi općenito } \\
\text { nisu previše sretni. Iako } \\
\text { nisu tužni, nikad ne }\end{array}$ & 2,2 & 2,0 & 1,12 & $0,21^{* *}$ & 1 & 5 & 0,67 & $-0,33$ \\
izgledaju sretni koliko bi \\
mogli biti. Ja sam takva \\
osoba.
\end{tabular}




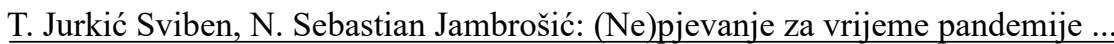

Tablica 3. (nastavak) Deskriptivna obilježja kontinuiranih varijabli

\begin{tabular}{|c|c|c|c|c|c|c|c|c|}
\hline & $\mathbf{M}$ & C & SD & $\mathbf{Z}$ & $\min$ & $\max$ & Skew. & Kurt. \\
\hline $\begin{array}{l}\text { 16a Nezadovoljan/na sam } \\
\text { radi ukidanja pjevanja uživo } \\
\text { tijekom pandemije. }\end{array}$ & 3,1 & 3,0 & 1,27 & $0,20 * *$ & 1 & 5 & $-0,23$ & $-0,86$ \\
\hline $\begin{array}{l}\text { 16b Pjevanje uživo na satu } \\
\text { Glazbenog kulture mi jako } \\
\text { nedostaje. }\end{array}$ & 3,3 & 3,0 & 1,28 & $0,18 * *$ & 1 & 5 & $-0,37$ & $-0,80$ \\
\hline $\begin{array}{l}\text { 16c Bez pjevanja osjećam } \\
\text { se manje sretnom osobom. }\end{array}$ & 3,0 & 3,0 & 1,25 & $0,17 * *$ & 1 & 5 & $-0,04$ & $-0,94$ \\
\hline $\begin{array}{l}\text { 16d Tijekom obustave } \\
\text { pjevanja bavim se novim, } \\
\text { drukčijim aktivnostima }\end{array}$ & 3,3 & 3,0 & 1,26 & $0,20 * *$ & 1 & 5 & $-0,38$ & $-0,81$ \\
\hline $\begin{array}{l}16 \text { e Bez pjevanja teže mi je } \\
\text { ukloniti negativne osjećaje. }\end{array}$ & 2,9 & 3,0 & 1,33 & $0,15^{* *}$ & 1 & 5 & 0,06 & $-1,14$ \\
\hline $\begin{array}{l}\text { 16f Radije bih pjevao/la } \\
\text { u virtualnom okruženju } \\
\text { (online) nego ne pjevao/la } \\
\text { uopće. }\end{array}$ & 2,9 & 3,0 & 1,39 & $0,16 * *$ & 1 & 5 & $-0,01$ & $-1,26$ \\
\hline 17 Kombinacija pjevanja. & 2,0 & 2,0 & 0,74 & $0,23 * *$ & 1 & 3 & $-0,06$ & $-1,18$ \\
\hline $\begin{array}{l}\text { 18a Pjevanje uživo me čini } \\
\text { sretnijom osobom. }\end{array}$ & 3,8 & 4,0 & 1,17 & $0,25 * *$ & 1 & 5 & $-0,88$ & $-0,03$ \\
\hline 18b Volim pjevati uživo. & 3,9 & 4,0 & 1,12 & $0,25 * *$ & 1 & 5 & $-0,90$ & 0,01 \\
\hline $\begin{array}{l}\text { 18c Pjevanje uživo me } \\
\text { opušta. }\end{array}$ & 3,7 & 4,0 & 1,19 & $0,24 * *$ & 1 & 5 & $-0,68$ & $-0,42$ \\
\hline $\begin{array}{l}\text { 18d Nakon pjevanja uživo } \\
\text { osjećam se sretnije i } \\
\text { pozitivnije. }\end{array}$ & 3,7 & 4,0 & 1,16 & $0,24 * *$ & 1 & 5 & $-0,72$ & $-0,32$ \\
\hline $\begin{array}{l}\text { 18e Pjevanje uživo mi } \\
\text { pomaže ukloniti negativne } \\
\text { osjećaje. }\end{array}$ & 3,6 & 4,0 & 1,20 & $0,19 * *$ & 1 & 5 & $-0,45$ & $-0,69$ \\
\hline $\begin{array}{l}18 \mathrm{f} \text { Zbog pjevanja uživo } \\
\text { osjećam optimizam prema } \\
\text { budućnosti. }\end{array}$ & 3,4 & 3,0 & 1,14 & $0,19 * *$ & 1 & 5 & $-0,40$ & $-0,48$ \\
\hline $\begin{array}{l}\text { 18g Osjećam da mi je } \\
\text { pjevanje uživo važno. }\end{array}$ & 3,4 & 4,0 & 1,24 & $0,20 * *$ & 1 & 5 & $-0,48$ & $-0,67$ \\
\hline $\begin{array}{l}\text { 18h Pjevanje uživo u meni } \\
\text { budi osjećaj nelagode. }\end{array}$ & 2,4 & 2,0 & 1,26 & $0,22 * *$ & 1 & 5 & 0,59 & $-0,66$ \\
\hline $\begin{array}{l}\text { 19a Pjevanje u virtualnom } \\
\text { okruženju (online) me čini } \\
\text { sretnijom osobom. }\end{array}$ & 2,6 & 3,0 & 1,12 & $0,20 * *$ & 1 & 5 & 0,10 & $-0,71$ \\
\hline
\end{tabular}


Tablica 3. (nastavak) Deskriptivna obilježja kontinuiranih varijabli

\begin{tabular}{|c|c|c|c|c|c|c|c|c|}
\hline & $\mathbf{M}$ & C & SD & $\mathbf{Z}$ & $\min$ & $\max$ & Skew. & Kurt. \\
\hline $\begin{array}{l}\text { 19b Volim pjevati na } \\
\text { daljinu. }\end{array}$ & 2,6 & 3,0 & 1,15 & $0,19 * *$ & 1 & 5 & 0,31 & $-0,68$ \\
\hline $\begin{array}{l}\text { 19c Pjevanje na daljinu me } \\
\text { opušta. }\end{array}$ & 2,5 & 2,0 & 1,12 & $0,20 * *$ & 1 & 5 & 0,38 & $-0,55$ \\
\hline $\begin{array}{l}\text { 19d Nakon pjevanja u } \\
\text { virtualnom okruženju } \\
\text { (online) osjećam se sretnije } \\
\text { i pozitivnije. }\end{array}$ & 2,6 & 3,0 & 1,10 & $0,18 * *$ & 1 & 5 & 0,19 & $-0,63$ \\
\hline $\begin{array}{l}\text { 19e Pjevanje u virtualnom } \\
\text { okruženju (online) mi } \\
\text { pomaže ukloniti negativne } \\
\text { osjećaje. }\end{array}$ & 2,6 & 3,0 & 1,20 & $0,17 * *$ & 1 & 5 & 0,26 & $-0,78$ \\
\hline $\begin{array}{l}\text { 19f Zbog pjevanja u } \\
\text { virtualnom okruženju } \\
\text { (online) osjećam optimizam } \\
\text { prema budućnosti. }\end{array}$ & 2,6 & 3,0 & 1,12 & $0,18 * *$ & 1 & 5 & 0,29 & $-0,57$ \\
\hline $\begin{array}{l}\text { 19g Osjećam da mi je } \\
\text { pjevanje u virtualnom } \\
\text { okruženju (online) važno. }\end{array}$ & 2,5 & 3,0 & 1,18 & $0,18^{* *}$ & 1 & 5 & 0,35 & $-0,69$ \\
\hline $\begin{array}{l}\text { 19h Pjevanje u virtualnom } \\
\text { okruženju (online) u meni } \\
\text { budi osjećaj nelagode. }\end{array}$ & 2,8 & 3,0 & 1,31 & $0,17 * *$ & 1 & 5 & 0,13 & $-1,11$ \\
\hline $\begin{array}{l}\text { 20a Pjevanje uživo u } \\
\text { zboru i/ili sastavu mi jako } \\
\text { nedostaje. }\end{array}$ & 3,7 & 4,0 & 1,39 & $0,22 * *$ & 1 & 5 & $-0,74$ & -0.71 \\
\hline $\begin{array}{l}\text { 20b Više mi nedostaje } \\
\text { pjevanje u zboru nego } \\
\text { pjevanje na satu Glazbene } \\
\text { kulture. }\end{array}$ & 3,2 & 3,0 & 1,39 & $0,17 * *$ & 1 & 5 & $-0,21$ & $-1,23$ \\
\hline $\begin{array}{l}\text { 20c Nedostaju mi nastupi } \\
\text { uživo. }\end{array}$ & 3,7 & 4,0 & 1,41 & $0,23 * *$ & 1 & 5 & $-0,68$ & $-0,83$ \\
\hline
\end{tabular}

LEGENDA. M - aritmetička sredina, C - centralna vrijednost, SD - standardna devijacija, Z - vrijednost Kolmogorov Smirnov testa pri testiranju normaliteta distribucije, min - najmanji rezultat, max - najveći rezultat, Skew - asimetričnost distribucije, Kurt - spljoštenost distribucije; ** - statistički značajno uz $1 \%$ rizika

Rezultati u Tablici 3. prvenstveno pokazuju da sve kontinuirane varijable imaju distribuciju rezultata statistički značajno različitu od normalne raspodjele. Ipak, sve varijable imaju asimetričnost i spljoštenost u granicama normale, odnosno manje od 3 i 10 (Kline, 1998) pa je i dalje opravdano korištenje parametrijskih statističkih postupaka s obzirom na to što se radi o dovoljno velikom broju ispitanika. 
Dodatno, što se tiče skale sreće, rezultati uglavnom pokazuju da se učenici percipiraju sretnima. Tvrdnje koje govore o sreći imaju vrijednosti oko 4 (slažem se), a tvrdnje koje govore o nedostatku sreće oko 2 (ne slažem se).

Tvrdnje vezane uz nezadovoljstvo oko pjevanja uglavnom postižu prosječnu ocjenu oko 3 (niti se slažem niti se ne slažem), a one oko nezadovoljstva oko pjevanja u zboru oko 4 (slažem se).

Pjevanje uživo ima ocjene koje su također blizu ocjene 4 (slažem se), dok pjevanje na daljinu ima ocjene blizu 3 (niti se slažem niti se ne slažem).

\section{REZULTATI I RASPRAVA}

\section{OSOBNO NEZADOVOLJSTVO (SREĆA) I PERCEPCIJA NEZADOVOLJSTVA OBUSTAVOM PJEVANJA}

U ovom dijelu željelo se istražiti postoji li razlika u percepciji nezadovoljstva obustavom pjevanja kod učenika ovisno o tome bave li se uopće i koliko se bave pjevanjem. Dodatno je za potrebe istraživanja provjereno postoji li razlika u tome koliko su učenici sretni općenito ovisno o tome pjevaju li ili uopće ne pjevaju (Tablica 4.).

Tablica 4. Rezultati t-testa pri testiranju razlike u osjećaju sreće i nezadovoljstvu radi ukidanja pjevanja ovisno o tome jesu li učenici prije pandemije bolesti COVID-19 pjevali ili uopće nisu pjevali $(d f=1057)$

\begin{tabular}{|c|c|c|c|}
\hline & $\mathbf{t}$ & Mnp & Мp \\
\hline 15a Sretna sam osoba. & $-2,23 *$ & 4,0 & 4,2 \\
\hline $\begin{array}{l}\text { 15b Kad se usporedim sa svojim vršnjacima ja sam manje } \\
\text { sretan/a. }\end{array}$ & 0,28 & 2,3 & 2,2 \\
\hline $\begin{array}{l}\text { 15c Neki su ljudi općenito vrlo sretni, bez obzira na to što im } \\
\text { se događa u životu. Ja sam takva osoba. }\end{array}$ & $-1,05$ & 3,2 & 3,3 \\
\hline $\begin{array}{l}\text { 15d Neki ljudi općenito nisu previše sretni. Iako nisu tužni, nikad } \\
\text { ne izgledaju sretni koliko bi mogli biti. Ja sam takva osoba. }\end{array}$ & 0,84 & 2,3 & 2,2 \\
\hline 15e Zadovoljan/na sam svojim životom kao cjelinom. & $-2,35^{*}$ & 3,9 & 4,1 \\
\hline $\begin{array}{l}\text { 16a Nezadovoljan/na sam radi ukidanja pjevanja uživo tijekom } \\
\text { pandemije. }\end{array}$ & $-6,08 * *$ & 2,5 & 3,2 \\
\hline 16b Pjevanje uživo na satu Glazbenog kulture mi jako nedostaje. & $-9,09 * *$ & 2,4 & 3,4 \\
\hline 16c Bez pjevanja osjećam se manje sretnom osobom. & $-7,02 * *$ & 2,3 & 3,1 \\
\hline $\begin{array}{l}\text { 16d Tijekom obustave pjevanja bavim se novim, drukčijim } \\
\text { aktivnostima. }\end{array}$ & $-3,93 * *$ & 2,9 & 3,4 \\
\hline 16 e Bez pjevanja teže mi je ukloniti negativne osjećaje. & $-4,08 * *$ & 2,5 & 2,9 \\
\hline $\begin{array}{l}\text { 16f Radije bih pjevao/la u virtualnom okruženju (online) nego } \\
\text { ne pjevao/la uopće. }\end{array}$ & $-4,17 * *$ & 2,4 & 3,0 \\
\hline
\end{tabular}

LEGENDA. $\mathrm{t}$ - vrijednost pri testiranju razlike između dviju aritmetičkih sredina, Mnp aritmetička sredina za one koji uopće ne pjevaju, Mp aritmetička sredina za one koji pjevaju, * - statistički značajno uz $5 \%$, ** - statistički značajno uz $1 \%$ rizika 
Rezultati u Tablici 4. pokazuju da postoji statistički značajna razlika kod dvije tvrdnje vezane uz sreću i to: Sretna sam osoba $(\mathrm{t}(1057)=-2,23 ; \mathrm{p}<0,05)$ i Zadovoljan/na sam svojim životom kao cjelinom $(\mathrm{t}(1057)=-2,35 ; \mathrm{p}<0,05) \mathrm{i}$ da je kod obje tvrdnje rezultat veći za učenike koji pjevaju $(\mathrm{M}=4,2$ i $\mathrm{M}=4,1)$ u odnosu na one koji uopće ne pjevaju ( $\mathrm{M}=4,0$ i $\mathrm{M}=3,9)$.

Što se tiče nezadovoljstva radi ukidanja pjevanja uživo tijekom pandemije, kod svih tvrdnji u ovome istraživanju postoje statistički značajne razlike. Kod svih tvrdnji je rezultat viši za učenike koji pjevaju u odnosu na one koji uopće ne pjevaju, odnosno oni koji pjevaju više misle da su nezadovoljni radi ukidanja pjevanja uživo tijekom pandemije, da im pjevanje uživo na satu Glazbene kulture jako nedostaje, da se bez pjevanja osjećaju manje sretnom osobom, da se tijekom obustave pjevanja bave novim, drukčijim aktivnostima, da im je bez pjevanja teže ukloniti negativne osjećaje i da bi radije pjevali u virtualnom okruženju (online) nego ne pjevali uopće.

Ovime je potvrđena hipoteza (H1) vezana uz nezadovoljstvo pjevanjem koje je veće kod onih koji su prije pandemije pjevali u odnosu na one koji nisu pjevali. Rezultati nisu začudni jer je očekivano da su učenici, koji se dobrovoljno uključuju u pjevačke aktivnosti kako na glazbenoj nastavi tako i na samostalno izabranim izvannastavnim i izvanškolskim glazbenim aktivnostima skupnog muziciranja, motivirani za pjevanje te su navikli da određen dio vremena provode u aktivnosti uz koju vežu pozitivne emocije. Kada im je taj vid ostvarivanja zadovoljstva uskraćen ili ograničen, osjećaju nedostatak, osjećaju se manje zadovoljno te nastoje pronalaziti nove izvore pozitivnih emocija.

Što se tiče sreće, iako to nije bilo postavljeno u hipotezama, pokazano je da na nekim varijablama postoji povećana osobna sreća kod onih koji pjevaju u odnosu na one koji uopće ne pjevaju.

Dobiveni rezultati podudaraju se s rezultatima ranijih istraživanja (Clift i Morrison, 2011; Clift i sur., 2017) u kojima se proučavao utjecaj grupnog pjevanje na osobnu dobrobit pjevača u rasponu od sedam mjeseci. Rezultati su pokazali da su sudionici doživjeli smanjenje osobnog nezadovoljstva i stresa te pokazali značajan porast osobne dobrobiti, osobnog zadovoljstva i optimizma. Slična studija provedena je u Australiji (Williams i sur., 2018) u kojoj su sudjelovali zborski pjevači s kroničnim mentalnim poremećajima. Studija je također prikazala značajan porast optimizma, osobne dobrobiti i osobnog zadovoljstva već u prvoj godini sudjelovanja u pjevačkom zboru. Iako su ispitanici navedenih studija srednje i zrelije dobi, a ispitanici ovog istraživanja mlađe dobi, usporedbom rezultata daje se zaključiti da pjevanje i pjevanje u skupini ima znatan pozitivan utjecaj na zadovoljstvo i osobnu dobrobit pjevača. Upravo ovaj zaključak otvara mogućnost za daljnje istraživanje koje bi obuhvatilo pjevače različite životne dobi i u kojem bi se ispitao intenzitet osobnog zadovoljstva i dobrobiti u odnosu na dob. 
Također, rezultati potvrđuju da učenici većim dijelom osjećaju pozitivan utjecaj pjevanja te da što je veći vremenski intenzitet koji provode baveći se tom aktivnošću to je veći intenzitet nezadovoljstva njegovom obustavom, tj. određenom restrikcijom zbog pandemije. Potrebno bi bilo dalje istražiti intenzitet osobnog nezadovoljstva s obzirom na dob pjevača.

Kako je osnovni problem istraživanja bio istražiti ima li razlike između onih koji pjevaju samo na satu Glazbene kulture i onih koji pjevaju drugdje tako su za daljnje ispitivanje isključeni učenici koji uopće ne pjevaju i provjerene su iste razlike kao i u Tablici 4. za ove dvije skupine ispitanika.

Tablica 5. Rezultati t-testa pri testiranju razlike u osjećaju sreće $i$ nezadovoljstvu radi ukidanja pjevanja ovisno o tome jesu li učenici prije pandemije pjevali samo na satu Glazbene kulture ili i drugdje $(d f=911)$

\begin{tabular}{|c|c|c|c|}
\hline & $\mathbf{t}$ & Mgk & Мp \\
\hline 15a Sretna sam osoba. & 1,60 & 4,2 & 4,1 \\
\hline $\begin{array}{l}\text { 15b Kad se usporedim sa svojim vršnjacima ja sam manje } \\
\text { sretan/a. }\end{array}$ & $-1,86$ & 2,2 & 2,3 \\
\hline $\begin{array}{l}\text { 15c Neki su ljudi općenito vrlo sretni, bez obzira na to što im } \\
\text { se događa u životu. Ja sam takva osoba. }\end{array}$ & $-0,12$ & 3,3 & 3,4 \\
\hline $\begin{array}{l}\text { 15d Neki ljudi općenito nisu previše sretni. Iako nisu tužni, } \\
\text { nikad ne izgledaju sretni koliko bi mogli biti. Ja sam takva } \\
\text { osoba. }\end{array}$ & -0.22 & 2,2 & 2,2 \\
\hline 15e Zadovoljan/na sam svojim životom kao cjelinom. & 1,50 & 4,2 & 4,1 \\
\hline $\begin{array}{l}\text { 16a Nezadovoljan/na sam radi ukidanja pjevanja uživo tijekom } \\
\text { pandemije. }\end{array}$ & $-8,25^{* *}$ & 2,9 & 3,6 \\
\hline $\begin{array}{l}\text { 16b Pjevanje uživo na satu Glazbenog kulture mi jako } \\
\text { nedostaje. }\end{array}$ & $-6,24 * *$ & 3,2 & 3,8 \\
\hline 16c Bez pjevanja osjećam se manje sretnom osobom. & $-7,49 * *$ & 2,8 & 3,5 \\
\hline $\begin{array}{l}\text { 16d Tijekom obustave pjevanja bavim se novim, drukčijim } \\
\text { aktivnostima. }\end{array}$ & $-0,69$ & 3,3 & 3,4 \\
\hline 16e Bez pjevanja teže mi je ukloniti negativne osjećaje. & $-3,74 * *$ & 2,8 & 3,2 \\
\hline $\begin{array}{l}\text { 16f Radije bih pjevao/la u virtualnom okruženju (online) nego } \\
\text { ne pjevao/la uopće. }\end{array}$ & $-3,33 * *$ & 2,8 & 3,2 \\
\hline
\end{tabular}

LEGENDA. $\mathrm{t}$ - vrijednost pri testiranju razlike između dviju aritmetičkih sredina, Mgk aritmetička sredina za one koji pjevaju samo na satu glazbene kulture, Mp aritmetička sredina za one koji pjevaju i drugdje, ** - statistički značajno uz $1 \%$ rizika

Rezultati u Tablici 5. pokazuju da nema razlike u osjećaju sreće, ali ima u gotovo svim tvrdnjama vezanim uz nezadovoljstvo radi ukidanja pjevanja uživo tijekom pandemije (jedino ne kod tvrdnje „Tijekom obustave pjevanja bavim se novim, drukčijim aktivnostima"). U svim slučajevima srednje vrijednosti su više za one učenike koji pjevaju i drugdje, a ne samo na satu Glazbene 
kulture, tj. kod onih koji pjevaju i drugdje nezadovoljstvo je veće. Odnosno, oni koji pjevaju i drugdje, a ne samo na satu Glazbene kulture više misle da su nezadovoljni radi ukidanja pjevanja uživo tijekom pandemije, da im pjevanje uživo na satu Glazbene kulture jako nedostaje, da se bez pjevanja osjećaju manje sretnom osobom, da im je bez pjevanja teže ukloniti negativne osjećaje i da bi radije pjevali u virtualnom okruženju (online)nego ne pjevali uopće.

Ovime je dodatno potvrđena hipoteza (H1) vezana uz nezadovoljstvo pjevanjem koje je veće kod onih koji pjevaju i drugdje, a ne samo na satu Glazbene kulture.

Rezultati potvrđuju da učenicima nedostaje pjevanje uživo tijekom obustave pjevanja i nastave uživo te da posljedično osjećaju osobno nezadovoljstvo, odnosno da pjevači koji se vremenski više bave pjevačkom aktivnošću obustavom ili restrikcijom pjevanja osjećaju i veće nezadovoljstvo što posljedično utječe na opadanje osobne sreće i osobnog zadovoljstva. Budući da su određeni ispitanici naglasili da pjevaju u sastavima i/ili zborovima koji nisu u sklopu škole, potrebno bi bilo dalje istražiti intenzitet osobnog nezadovoljstva s obzirom na dob pjevača i vrste zborova.

I na kraju, u zadnjem dijelu ovoga problema, pretpostavljeno je da će učenici koji su se tijekom pandemije bavili online muziciranjem pokazivati pozitivnije emocije u odnosu na one koji su se prestali baviti glazbom. Dodatno je provjereno i što je s percipiranim nezadovoljstvom vezanim uz odsustvo pjevanja (Tablica 6.).

Tablica 6. Rezultati t-testa pri testiranju razlike u osjećaju sreće i nezadovoljstvu radi ukidanja pjevanja ovisno o tome jesu li učenici tijekom pandemije nastavili pjevati ili ne $(d f=746)$

\begin{tabular}{|c|c|c|c|}
\hline & $\mathbf{t}$ & Мp & Mnp \\
\hline 15a Sretna sam osoba. & 1,82 & 4,2 & 4,1 \\
\hline $\begin{array}{l}15 \mathrm{~b} \text { Kad se usporedim sa svojim vršnjacima ja sam manje } \\
\text { sretan/a. }\end{array}$ & 1,40 & 2,3 & 2,2 \\
\hline $\begin{array}{l}\text { 15c Neki su ljudi općenito vrlo sretni, bez obzira na to što im } \\
\text { se događa u životu. Ja sam takva osoba. }\end{array}$ & $2,89 * *$ & 3,5 & 3,2 \\
\hline $\begin{array}{l}\text { 15d Neki ljudi općenito nisu previše sretni. Iako nisu tužni, } \\
\text { nikad ne izgledaju sretni koliko bi mogli biti. Ja sam takva } \\
\text { osoba. }\end{array}$ & 0,11 & 2,2 & 2,2 \\
\hline 15e Zadovoljan/na sam svojim životom kao cjelinom. & 0,44 & 4,2 & 4,1 \\
\hline $\begin{array}{l}\text { 16a Nezadovoljan/na sam radi ukidanja pjevanja uživo } \\
\text { tijekom pandemije. }\end{array}$ & $3,67 * *$ & 3,4 & 3,1 \\
\hline $\begin{array}{l}\text { 16b Pjevanje uživo na satu Glazbenog kulture mi jako } \\
\text { nedostaje. }\end{array}$ & $4,14 * *$ & 3,8 & 3,4 \\
\hline 16c Bez pjevanja osjećam se manje sretnom osobom. & $3,46^{* *}$ & 3,3 & 3,0 \\
\hline
\end{tabular}


$\underline{\text { T. Jurkić Sviben, N. Sebastian Jambrošić: (Ne)pjevanje za vrijeme pandemije ... }}$

Tablica 6. (nastavak) Rezultati t-testa pri testiranju razlike u osjećaju sreće $i$ nezadovoljstvu radi ukidanja pjevanja ovisno o tome jesu li učenici tijekom pandemije nastavili pjevati ili ne $(d f=746)$

\begin{tabular}{|c|c|c|c|}
\hline & $\mathbf{t}$ & Мp & Mnp \\
\hline $\begin{array}{l}\text { 16d Tijekom obustave pjevanja bavim se novim, drukčijim } \\
\text { aktivnostima. }\end{array}$ & 1,60 & 3,4 & 3,3 \\
\hline 16 e Bez pjevanja teže mi je ukloniti negativne osjećaje. & $2,78 * *$ & 3,2 & 2,9 \\
\hline $\begin{array}{l}\text { 16f Radije bih pjevao/la u virtualnom okruženju (online) nego } \\
\text { ne pjevao/la uopće. }\end{array}$ & $6,66^{* *}$ & 3,4 & 2,7 \\
\hline
\end{tabular}

LEGENDA: $\mathrm{t}$ - vrijednost pri testiranju razlike između dviju aritmetičkih sredina, $\mathrm{Mp}$ aritmetička sredina za one koji su nastavili pjevati tijekom pandemije, Mnp - aritmetička sredina za one koji su prestali pjevati u pandemiji, ** - statistički značajno uz $1 \%$ rizika

Rezultati u Tablici 6. donose informaciju da učenici koji su nastavili pjevati u pandemiji postižu statistički značajno $(\mathrm{t}(746)=2,89 ; \mathrm{p}<0,01)$ viši rezultat $(\mathrm{M}=3,5)$ na tvrdnji „Neki su ljudi općenito vrlo sretni, bez obzira na to što im se događa u životu. Ja sam takva osoba." u odnosu na one koji nisu nastavili pjevati tijekom pandemije $(\mathrm{M}=3,2)$.

Kod nezadovoljstva ukidanjem pjevanja, postoji više razlika (Nezadovoljan/ na sam radi ukidanja pjevanja uživo tijekom pandemije, Pjevanje uživo na satu Glazbenog kulture mi jako nedostaje, Bez pjevanja osjećam se manje sretnom osobom, Bez pjevanja teže mi je ukloniti negativne osjećaje te Radije bih pjevao/la u virtualnom okruženju nego ne pjevao/la uopće) između dvije skupine. Kod svih tvrdnji skupina koja je nastavila pjevati postiže više rezultate, odnosno oni koji pjevaju i u pandemiji više misle da su nezadovoljni radi ukidanja pjevanja uživo tijekom pandemije, da im pjevanje uživo na satu Glazbenog kulture jako nedostaje, da se bez pjevanja osjećaju manje sretnom osobom, da se tijekom obustave pjevanja bave novim, drukčijim aktivnostima, da im je bez pjevanja teže ukloniti negativne osjećaje i da bi radije pjevali u virtualnom okruženju (online) nego ne pjevali uopće.

Ovime je potvrđen samo manji dio hipoteze $(\mathrm{H} 2)$ vezan uz osjećaj sreće kod onih koji nastavljaju pjevati u pandemiji u odnosu na one koji u pandemiji prestaju s pjevanjem. Dodatno su rezultati pokazali da oni koji nastavljaju pjevati u pandemiji imaju veće nezadovoljstvo oko ukidanja pjevanja.

Učenici koji su pjevali tijekom pandemije to su činili uz određene uvjete i restrikcije kao što je manji broj učenika u razredu, nošenje maske, tiho pjevanje, održavanje osobne distance (vidi: Odluka o načinu izvođenja nastave u osnovnim i srednjim školama kao i na visokim učilištima te obavljanju rada u ustanovama predškolskog odgoja i obrazovanja u uvjetima epidemije bolesti COVID-19). Pjevanje u ograničavajućim uvjetima znatno odudara od uobičajenog načina prema kojem se odvijaju aktivnosti pjevanja što učenici uglavnom nisu pozitivno prihvatili. 


\section{RAZLIKA U PERCEPCIJI PJEVANJA UŽIVO I PJEVANJA U VIRTUALNOM OKRUŽENJU (ONLINE)}

Dodatno je u ovome istraživanju ispitano postoji li razlika u percepciji pjevanja uživo i pjevanja u virtualnom okruženju (online). U ovom dijelu obrađeni su samo podatci onih učenika koji su pjevali uživo te u pandemiji pjevali u virtualnom okruženju $(\mathrm{N}=273)$. Rezultati su obrađeni t-testom za zavisna mjerenja kako bi se usporedila razlika u pjevanju u virtualnom okruženju (online) i pjevanju uživo odnosno da se provjeri hipoteza (H3) smatraju li učenici koji su iskusili i pjevanje uživo i pjevanje u virtualnom okruženju (online) da pjevanje uživo ima veći učinak od pjevanja u virtualnom okruženju (online).

Rezultati su prikazani u Tablici 7.

Tablica 7. Rezultati t-testa pri testiranju razlike u percepciji pjevanja uživo i pjevanja $u$ virtualnom okruženju (,,online“) $(d f=272)$

\begin{tabular}{lccc}
\hline & $\mathbf{t}$ & $\mathbf{M u}$ & $\mathbf{M o}$ \\
\hline ...me čini sretnijom osobom & $13,63^{* *}$ & 3,8 & 2,6 \\
Volim... & $14,26^{* *}$ & 3,9 & 2,6 \\
...me opušta & $13,51^{* *}$ & 3,7 & 2,5 \\
Nakon ... osjećam se sretnije i pozitivnije & $13,82^{* *}$ & 3,7 & 2,6 \\
...mi pomaže ukloniti negativne osjećaje & $11,35^{* *}$ & 3,6 & 2,6 \\
Zbog...osjećam optimizam prema budućnosti & $10,56^{* *}$ & 3,4 & 2,6 \\
Osjećam da mi je...važno & $10,88^{* *}$ & 3,4 & 2,5 \\
...u meni budi osjećaj nelagode & $-3,92^{* *}$ & 2,4 & 2,8 \\
\hline
\end{tabular}

LEGENDA. $\mathrm{t}$ - vrijednost pri testiranju razlike između dviju aritmetičkih sredina, $\mathrm{Mu}-$ aritmetička sredina za pjevanje uživo, Mo - aritmetička sredina za one koji pjevaju online, ** - statistički značajno uz $1 \%$ rizika

Prema očekivanjima temeljem postavljene hipoteze (H3), sve razlike između pjevanja uživo i pjevanja u virtualnom okruženju (online) su statistički značajne. Kod svih tvrdnji je srednja vrijednost za pjevanje uživo statistički značajno viša nego srednja vrijednost za pjevanje u virtualnom okruženju (online) osim kod tvrdnje ,...u meni budi osjećaj nelagode“ koja je negativnog smjera te ima viši rezultat kod pjevanja u virtualnom okruženju (online). Drugim riječima pjevanje uživo ih čini sretnijom osobom, više ga vole, važnije im je, znatnije ih opušta, više uklanja negativne osjećaje, osjećaju se radi njega sretnije i pozitivnije te su optimističniji prema budućnosti.

Multimedijske tehnologije omogućuju novi pristup nastavnim sadržajima. „Medijsko okruženje za učenje odnosno obrazovanje obogaćeno je u zadnjih petnaestak godina brojnim obrazovnim projektima na najvećoj komunikacijskoj mreži koju je čovječanstvo ikad stvorilo - internetu“" (Matasić i Dumić, 2012, str. 144). Ipak, uzevši specifičnost glazbene nastave i razvijenost te 
pripremljenost tehnologije za nastavu na daljinu u vrijeme pandemije, postojeće platforme nisu bile spremne niti su mogle omogućiti pravilno sinkroniziranje zvuka kojim bi se u potpunosti mogle zadovoljiti potrebe nastave glazbe, tj. provoditi aktivnosti grupnog muziciranja. Ipak, učitelji Glazbene kulture učinili su iskorak i prema odgovorima anketiranih učenika vidljivo je da su na svojevrstan način pokušali zadovoljiti potrebu učenika za pjevanjem. Prema izjavama učenika o načinu odvijanja nastave glazbe i pjevačkih aktivnosti te zastupljenim tehnologijama vidljivo je da su se pojedini učitelji prilagođavali u načinima zadavanja zadataka za rad kod kuće (za domaći rad naučiti pjesmu ili pjevati već neku poznatu, pjevati svaki dan pjesmu po izboru, izraditi video ili audiosnimku vlastitog pjevanja, pjevati uz glazbu na YouTube ili sl. platformi) ili se pokušavalo s učenicima pjevati direktno u virtualnom okruženju (online) koristeći platforme Teams, Zoom, Meet i sl., češće u manjim grupama. O tome svjedoče izdvojene izjave učenika: „Da, pjevao sam kod kuće“, „pjevali smo koristeći aplikaciju Teams“, „koristili smo Zoom“, „Pjevala sam samo onda kad nam je učiteljica nešto zadala da doma otpjevamo“, „Pjevam sama kod kuće“, „odustali smo zato jer bi bila mikrofonija“, „Koliko se sjećam nismo pjevali“, „Zadatci koje smo dobivali preko njih [digitalnih platformi] smo dobivali pjesme i pjevali svak’ za sebe“, „Dobili bi zadatke i pjevali pjesme“, „,sami smo učili pjesme“", ,Jesmo [pjevali], ali sami bez poziva [ne u sklopu nastave na daljinu]“, ,,jesmo [pjevali], preko aplikacije Teams, ali ja nisam jer zvuči glupo“, „pjevali smo kada smo odgovarali [provjera znanja]“, „pjevala sam sama kod svoje kuće, kada je učitelj rekao da naučimo neku pjesmu“, „snimali smo se kako pjevamo“, „snimili smo samo pjevanje i slali učitelju“, ,probali Zoom [pjevati koristeći aplikaciju Zoom], ali nije radilo pa smo samo [pjevali] na ispitu“, „U grupama smo pjevali na Zoom“...

Pjesme koje se uče i pjevaju na nastavi Glazbene kulture najčešće se usvajaju metodom učenja pjevanja po sluhu. „Iako se u literaturi mogu pronaći i prijedlozi drugih mogućih modela obrade novih pjesama, kao što je primjerice obrada pjesme po notnom zapisu, u primarnom obrazovanju nije potrebno koristiti se tom metodom, budući da ona zahtijeva niz razvijenih glazbenih kompetencija koje nije moguće razviti u okviru redovne nastave glazbe“ (RadočajJerković, 2017a, str. 78). Jedna od metoda koju učitelji tijekom usvajanja nove pjesme mogu koristiti je demonstracija pjesme audio/videosnimkom. Takav način može biti odstupanje od ustaljenog i preporučenog postupka učenja, no ne može zamijeniti učitelja, njegovo pjevanje u postupku usvajanja pjesme kao ni njegovo potrebno interveniranje i moderiranje procesa koje je temeljeno na iskustvu. (Radočaj-Jerković, 2017b)

Dakle, učitelj je medijator koji mora biti neposredno prisutan u procesu usvajanja pjesme te uz kojeg učenici putem aktivnog muziciranja sudjeluju u učenju nove pjesme. 
S obzirom na sve navedeno potvrđuje se teza da učenicima koji su se aktivno bavili pjevanjem i prije pandemije, pjevanje u virtualnom okruženju (online) ne može nadomjestiti u potpunosti pjevanje uživo kao ni kvalitetno usvajanje novih pjesama.

\section{ZAKLJUČAK}

Cilj istraživanja bio je uočiti postoji li razlika u percepciji nezadovoljstva obustavom pjevanja ovisno o tome jesu li se učenici prije pandemije bolesti COVID-19 aktivno i intenzivnije bavili pjevanjem u odnosu na one koji tu aktivnost nisu imali ili su ju imali u minimalnoj mjeri te postoji li razlika u percepciji pjevanja uživo i pjevanja u virtualnom okruženju (online).

Hipoteza vezana uz nezadovoljstvo pjevanjem koje je veće kod onih koji su prije pandemije pjevali u odnosu na one koji nisu pjevali je potvrđena kao i hipoteza vezana uz nezadovoljstvo pjevanjem koje je veće kod onih koji pjevaju i drugdje, a ne samo na satu Glazbene kulture.

Kod svih tvrdnji je rezultat viši za učenike koji pjevaju u odnosu na one koji uopće ne pjevaju, odnosno oni koji pjevaju više misle da su nezadovoljni radi ukidanja pjevanja uživo tijekom pandemije, da im pjevanje uživo na satu Glazbene kulture jako nedostaje, da se bez pjevanja osjećaju manje sretnom osobom, da se tijekom obustave pjevanja bave novim, drukčijim aktivnostima, da im je bez pjevanja teže ukloniti negativne osjećaje i da bi radije pjevali u virtualnom okruženju (online) nego ne pjevali uopće.

Istraživanjem je djelomično potvrđen manji dio hipoteze vezan uz osjećaj sreće kod učenika koji nastavljaju pjevati tijekom pandemije u odnosu na one koji u pandemiji prestaju s pjevanjem. Dodatno je pokazano da učenici koji su pjevali tijekom pandemije na nastavi uživo imaju veće nezadovoljstvo kada je pjevanje obustavljeno zbog nastave na daljinu.

Također, istraživanjem se pokazalo da na nekim varijablama postoji povećana osobna sreća kod onih učenika koji pjevaju u odnosu na one koji ne pjevaju. Nadalje, potvrđena je i teza da učenicima koji su se aktivno bavili pjevanjem i prije pandemije, pjevanje putem mrežnih platformi (online) ne može nadomjestiti u potpunosti pjevanje uživo kao ni kvalitetno učenje novih pjesama i skladbi.

Učenici koji su pjevali tijekom pandemije to su činili uz određene uvjete i restrikcije što znatno odudara od uobičajenog rada. Preporučuje se daljnje istraživanje u smislu efikasnosti takvog načina pjevanja te mogućih posljedica u odnosu na zdravlje, osobnu dobrobit i efikasnost provedbe takve aktivnosti.

Kako su određeni ispitanici naglasili da pjevaju u sastavima i/ili zborovima koji nisu u sklopu škole potrebno bi bilo dalje istražiti intenzitet osobnog nezadovoljstva s obzirom na dob pjevača i vrste zborova. 
Doprinos rada je u potvrđivanju ranijih istraživanja da pjevanje utječe pozitivno na pjevača te da kontinuirano prakticiranje stvara zdravu naviku koja pozitivno utječe na učenika pjevača jer se njezinom obustavom, kao što je rezultatima potvrđeno, intenzivira osobno nezadovoljstvo. Pokazuje također da učenici uvelike vole pjevati i da na osobnoj razini osjećaju potrebu za pjevanjem, tj. osjećaju nezadovoljstvo kada im je onemogućeno pjevanje.

Kako je pandemija bolesti COVID-19 novost koja je zatekla obrazovanje tako je otvorena mogućnost provjeriti korisnost nastave glazbe, tj. pjevanja $u$ obrazovanju kao i reakciju i potrebu učenika za pjevanjem na području cijele Republike Hrvatske i širem uzorku. Takav uvid do sada nije bio pružan u znanstvenom radu.

U istraživanju su ispitani i načini provođenja aktivnosti pjevanja tijekom nastave na daljinu koristeći različite platforme poput MS Teams, Zoom, Meet i sl. Takve platforme pokazale su da sustav nije bio spreman odgovoriti na pandemiju te da takve platforme i aplikacije (u tom periodu) nisu bile prikladne za pjevanje kao što je grupno pjevanje $u$ razredu ili pjevanje u sastavu ili zboru zbog različitih tehničkih poteškoća (sinkronizacija zvuka, kvaliteta zvuka, i sl.). Nadalje bi bilo potrebno istražiti koje su mogućnosti provedbe nastave grupnog simultanog pjevanja putem digitalnih platformi, njihovu efikasnost $\mathrm{i}$ mogućnosti ostvarenje zadanih ishoda kurikula.

Iako je tijekom najstrožih mjera pandemije bolesti COVID-19 sugerirana obustava pjevanja i u profesionalnim umjetničkim izvedbama i u obrazovnom procesu, literatura ukazuje na to da „trenutno nema dostupnih podataka koji pokazuju da postoji statistički značajan dodatni rizik od virusnog prijenosa od pjevanja povrh već ionako znatnog rizika u društvenom okupljanju u domaćim i javnim sredinama kada postoje odgovarajuće mjere ublažavanja“ (Wallce i sur., 2020). Na temelju postojećih rezultata ovoga istraživanja i istraživanja o štetnosti pjevanja u širenju virusa, moguće je dodatno propitivati dobrobiti odluke o restrikcijama pjevanja, odnosno otvora se prostor za buduća istraživanja o korelacijama restriktivnih mjera i posljedica na obrazovni sustav i posljedica na emocionalno stanje učenika te ograničavanje integrativnog razvojnog potencijala učenika.

\section{LITERATURA}

Balsnes, A. H. (2018). Singing for a better life: choral singing and public health. In L. Bonde, T. Theorell, (Ed.), Music and Public Health (pp. 167-186). Springer. Clift, S. (2012). Singing, wellbeing, and health. U G. Macdonald, L. Kreutz, L. Mitchell (Ed.), Music, Health \& Wellbeing (pp. 113-124). Oxford: Oxford University Press.

Clift, S., \& Morrison, I. (2011). Group singing fosters mental health and wellbeing: Findings from the East Kent 'singing for health' network project. Mental Health and Social Inclusion, 15, 88-89. https://doi.org/10.1108/20428301111140930 
Clift, S., Manship, S., Stephens, L. (2017). Further evidence that singing fosters mental health and wellbeing: the West Kent and Medway project. Ment Health Soc Inclusion, 21, 53-62.

Clift, S., Nicols, J., Raisbeck, M., Whitmore, C. and Morrison, I. (2010). Group singing, wellbeing and health: A systematic mapping of research evidence. UNESCO Journal, 2, 1, https://education.unimelb.edu.au/

Cohen, G. (2009.) New theories and research findings on the positive influence of music and art on health with ageing. Arts \& Health, 1, 48-63.

Gabrielsson A. (2012.) Strong Experiences With Music - Music is Much More Than Just Music. Oxford: Oxford University Press.

Gick, M. L. (2011). Singing, health and well-being: a health psychologist's review. Psychomusicology, 21, 176-207.

Grape, C., Sandgren, M., Hansson, L. O., Ericson, M. \& Theorell, T. (2003). Does singing promote well- being? An empirical study of professional and amateur singers during a singing 527 lesson. Integr Physiol Behav Sci., 38, 65-74.

Grushka, K., Lawry M., Sutherland, K., Fergusson, C. (2021). A Virtual Choir Ecology and the Zoom-machinic: Visual Technologies as a Panacea for Social Isolation. Video Journal of Education and Pedagogy, 1-16. http://doi:10.1163/23644583-bja10013

Hedden, D. (2012). An Overview of Existing Research about Children's Singing and the Implications for Teaching Children to Sing. Applications of Research in Music Education, 30(2), 52-62.

https://mzo.gov.hr/UserDocsImages/dokumenti/Publikacije/Predmetni/ Kurikulum\%20nastavnih\%20predmeta\%20Glazbena\%20kultura\%20i\%20 Glazbena\%20umjetnost\%20za\%20osnovne\%20skole\%20i\%20gimnazije.pdf

Kline, R. B. (1998). Principles and practice of structural equation modeling. New York: Guildford Press.

Matasić, I. \& Dumić, S. (2012). Multimedijske tehnologije u obrazovanju. Medijska istraživanja: znanstveno-stručni časopis za novinarstvo i medije, 18(1), 143-151.

MZO (2019). Kurikulum nastavnog predmeta Glazbena kultura za osnovne škole i Glazbena umjetnost za gimnazije.

Proleta, J. \& Svalina, V. (2011). Odgojna uloga izvannastavnih glazbenih aktivnosti. Život i škola, br. 26, 134-153.

Radočaj-Jerković, A. (2017a). Zborsko pjevanje u odgoju i obrazovanju. Umjetnička akademija u Osijeku.

Radočaj-Jerković, A. (2017b). Pjevanje u nastavi glazbe. Umjetnička akademija u Osijeku.

Radočaj-Jerković, A., Škojo, T., \& Milinović, M. (2018). Zborsko pjevanje kao oblik neformalnog učenja i njegov utjecaj na formiranje dječjih glazbenih preferencija. Školski vjesnik: časopis za pedagogijsku teoriju i praksu, 67(2), 311-329.

Rojko, P. (2005). Metodika nastave glazbe - Praksa II. dio. Naklada Jakša Zlatar.

Rojko, P. (2012). Metodika nastave glazbe. Teorijsko-tematski aspekti. Sveučilište Josipa Jurja Strossmayera, Pedagoški fakultet Osijek. 
Schladt, M., Nordmann, G. C., Emilius, R., Kudielka, B. M., de Jong, T. R. \& Neuman, I. D. (2017). Choir versus solo singing: effects on mood, and salivary oxytocin and cortisol concentrations. Front Hum Neurosci. 14(1) https://doi.org/10.3389/ fnhum.2017.00430.

Škojo, T. (2019). Odnos zborskih aktivnosti i dobrobiti pjevača amatera. In M. Kolar Billege (Ed.). Suvremene teme u odgoju i obrazovanju (pp. 225-226). Sveučilište u Zagrebu, Učiteljski fakultet.

Stensaeth K. (2018). Music as participation! exploring music's potential to avoid isolation and promote health. In Bonde L. O., T. Theorell (Ed.). Music and Public Health. London: Springer Books.

Šulentić Begić, J. \& Birtić V. (2012). Otvoreni model nastave glazbene kulture u primarnom obrazovanju u nekim osječkim osnovnim školama. Tonovi, 60, 72-84.

Šulentić Begić, J. \& Radičević, B. (2010). Pjevanje u prvim trima razredima osnovne škole. Život $i$ škola, 24(2), 243-252.

Theorell T. (2014). Psychological health effects of musical experiences. Theories, Studies and Reflections in Music Health Science. Dordrecht, Springer.

Upute za sprječavanje i suzbijanje epidemije covid-19 vezano za rad predškolskih ustanova, osnovnih i srednjih škola u školskoj godini 2020./2021. Hrvatski zavod za javno zdravstvo i Ministarstvo znanosti i obrazovanja. https://www.hzjz. hr/wp-content/uploads/2020/03/Upute_vrtici_i_skole_24_08_2020_HZJZ-1.pdf

Vickhoff, B., Malmgren, Åström R., Nyberg G., Ekström, S. R., Engwall, M., H., Snygg, J., Nilsson, M. \& Jörnsten, R. (2013). Music determines heart rate variability of singers. Front Cogn Neurosci. https://doi.org/10.3389/psyg.2013.00334

Vidulin, S. (2016). Extracurricular musical activities in primary school from the teachers' point of view. In Marek Sedláček (Ed.), Music Education - Terra Cognita? (pp. 6-22). Masarykova univerziteta.

Vidulin-Orbanić, S. \& Terzić, V. (2011). Polazište i pristup pjevanju u općeobrazovnoj školi. Metodički ogledi, 18(2), 137-156.

Wallce, J., Moscardini, L., Rae, A. \& Watson, A. (2020). A systematic literature review of studies surrounding singing and brass, woodwind and bagpipe playing during the COVID-19 pandemic. Following the Science. ME Scotland.

Welch, G. (2012). The benefits of singing for children: The physical, psychological, social, musical, and educational benefits of singing. Institute of Education, University of London. http://www.singup.org/fileadmin/singupfiles/The Benefits_of_Singing_for_Adolescents_by_Professor_Graham_Welch.pdf

Welch, G. F., Himonides, E., Saunders, J., Papageorgi, I., Rinta (2010). Researching the impact of the national singing programme 'Sing Up' in England: Main findings from the first three years (2007-2010). Children's singing development, self-concept and sense of social inclusion. Institute of Education, University of London. http://www.singup.org/fileadmin/singupfiles/previous_uploads/IoE_Sing_Up_ Phase_4_Evaluation_.pdf 
Welch, G. F., Himonides, E., Saunders, J., Papageorgi, Rinta, I., T., Preti, C., Stewart, C., Lani, J., Vraka, M. \& Hill, J. (2008). Researching the first year of the National singing programme in England: An initial impact evaluation of children's singing behaviours and singer creativity. Institute of Education, University of London. http://www.imerc.org/papers/nsp/NSPyr1.pdf

Welch, G., Himonides, E., Saunders, J., Papageorgi, I. \& Sarazin, M. (2014). Singing and social inclusion. Frontiers in psychology, 5, 803. https://doi:10.3389/ fpsyg.2014.00803

Williams E, Dingle G. A. \& Clift S. (2018). A systematic review of mental health and wellbeing outcomes of group singing for adults with a mental health condition. Eur J Public Health, 28, 1035-1042. https://europepmc.org/article/med/29982515 